134, 2, 151 (1953)

5) Perry, J. H. : "Chem. Eng. Handbook"

6）讼山卓藏：砏确, No.9, 34 (1963)

7) Lincoln, T. W. : Ind. \& Eng. Chem., 54, 3, 53, (1962)

8）奥田聡:5：未発表, 昭和 40 年秋発表の予定

9) Schäfer, E. : Chemische Ind., 13 [7] 416, (1961)

10) Schäfer, E. : Chemische Ind., 16 [6] 354, (1964)

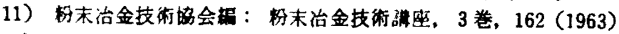

12）岡田辰ら：体お上び份末治金，2，2，58（1947）

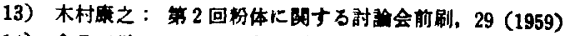

14）食品工学シリース 2 堂：食品工萧の固体粉体処理, 71, (1961) 光 琳豐院

15) Rumpf, H. : Chem. Ing. Tech., 8, 317 (1953)

16）松山年藏：化学工学, 23, [11] 723 (1959)

17) 同上：化学工学, 23, [11] 705 (1959)

18）同上：确 No. 2, 9 (1958)

19）美間博之：粉确, No. 7,23 (1961)
$\mathrm{XIX}-\mathrm{II} \cdot 3 \cdot(3)$ 耗 現 象*

神 保 元 二**

\section{1. 粉砕機中の摩耗}

粉确に㧍ける摩耗現象はきわめて大きい問題であって， 少し極端ないい方をすれば粉砕とは金属を消耗しなからら 固体の細分化を行な5,つまり“肉を切らせて骨を断つ” 操作なのである。したがってとくに鉣山関係では古くか らボールミル，ロッドミル中の媒体と内張りの摩耗につ いて虎大なデータが集積されてきている。しかし解析的 研究は意外に少ない。経験的なデータをすへてあげるの

表 1 摩耗速度指数の値 ((1)〜(10)のデータ以外佼椐（4）によった)

\begin{tabular}{|c|c|c|c|c|}
\hline & 研究者名 & $n$ の傳 & 発敖年 & 文塥 \\
\hline 1. & Davis & 3.00 & 1920 & - \\
\hline 2. & De Vaney \& Coghill & 2.00 & 1937 & - \\
\hline 3. & $(*-N)$ & 2.21 & $\begin{array}{c}1940 \\
\prime \prime\end{array}$ & (2)(3) \\
\hline 4. & Mortsell & $\begin{array}{l}2.99 \\
2.00\end{array}$ & $"$ & - \\
\hline 5. & Garms \& Stevens & 2.00 & 1946 & - \\
\hline \multirow[t]{2}{*}{6.} & Prentice $\quad\left(N<0.65 N_{c}\right)$ & 2.00 & $"$ & (9) \\
\hline & $\left(N>N_{c}\right.$ or $\left.D<11 / 4^{\prime \prime}\right)$ & 3.00 & $"$ & - \\
\hline 7. & Timmermans & 2.00 & 1947 & - \\
\hline 8. & Djingheusian & 2.00 & 1949 & - \\
\hline 9. & Norman \& Loeb & 2.00 & $"$ & - \\
\hline \multirow[t]{2}{*}{10.} & Norquist \& Moeller & 2.00 & 1950 & - \\
\hline & （高速回舩） & 3.00 & $"$ & \\
\hline 11. & Rasumow & 2.30 & 1954 & (10) \\
\hline 12. & $\begin{array}{l}\text { (低速回坛) } \\
\text { (高速回坛) }\end{array}$ & 2.00 & $"$ & f(5) \\
\hline 13. & Rose & $\begin{array}{l}3.00 \\
2.00\end{array}$ & 1958 & (11) \\
\hline 14. & Storek, Vrsek \& Likes & 3.00 & 1959 & (14) \\
\hline 15. & $\equiv$. & 2.16 & 1964 & (7) \\
\hline 16. & Bernutat & 2.00 & $"$ & (1) \\
\hline 17. & Paulsen & 2.00 & $"$ & (8) \\
\hline \multirow[t]{2}{*}{18.} & $(ホ i-ル)$ & 2.00 & " & $(15)$ \\
\hline & (シルべブ) & 3.00 & $"$ & (15) \\
\hline 19. & （たたし层娌：ル） & 3.00 & $"$ & (6) \\
\hline
\end{tabular}

* 昭和 40 年 6 月 20 日 受理

** Genji Jimbo 東京大学工学部
は不可能であるしまたあまり意味もないと思うので,こ こでは多少とも系統的な解析を試みているものを中心と してこ稆介したいと思5。なおこの問題はとくに鉱山関 係で活発に研究が行なわれており文献も多いか，筆者は その方面に暗いので見落している文献も少なくないと思 われる。こ教示いただければ幸いである。

\section{2. 麾の速度式}

ボールミル中の金属摩耗に関する実験・研究はほとん どが実用ミルを用いたものであるため，とりあげ5る因 子はきわめて限られたものとなり，ほとんどがボール径 $\left(D_{b}\right)$ の影整を求めているといっていいいであろ5。ま た定常状態に拈けるボール径の減少速度からミル中のボ 一ル径の分布は求まるので，それだけですかなり有用だ といえることも事実である。したがって摩耗速度式（重 量基算で現わして $\left.\left(d W_{0} / d t\right)\right)$ は次のよらなボール径の

$$
\frac{d W_{b}}{d t}=-k D_{b}{ }^{n}
$$

これが摩耗の基礎式であって，定数 $k, n$ のちち $n$ は $2 \leq n \leq 3$ であると考えられており，事実数多くの実験結 果は衰1にまとめたよ5に大体 2 と 3 の間にきている。 一般には衙等が強いはど $n=3$ に近くボール重田に比例 関係となり，強いはど2に近ついてボールの表面に比例 するよ5になると考えられている。また実験室的に均一 径ボールで測定をした場合と，工羊的ミルでボール径分 布がある状热での測定とでは明らかに臬いがあるはずで あるが、このような点についても検討をしていく必要が あろう。 関数としてあらわされることが多い。 


\section{3. ボールの粒往分布}

Rasumow ${ }^{11}$ は摩耗の基磼式（1）から，ボールのミ ル中の滞留時間（ボールが消隇するまでの時間），任意 の時間に淤るボールの重量, 定常状態でのボールの粒 径分布式などを導いているが，最後の関係は Bond, Paulsen9) らも求めていて，次のようにあらわされる。

$$
R_{b} \doteqdot 1-\left(\frac{D_{b}}{D_{0}}\right)^{6-n}
$$

ここで $R_{0}$ は $D_{b}$ より小さいボールの累積パーセント， $D_{0}$ ははじめにチャージしたボールの径, $n$ は（1）式の 指数である，

（2）式によればミル中のボールの径と累程パーセント は両対数上で直線になるはずであるが，これは Bond をはしめ, Paulsen")，三耣8)らによって確かめられて いる。したがってこの分布四の勾配上り（2）式の (6-n)が求まり，それから $n$ の值を計算できるわけで ある。

\section{4. その他の諸因子の影霎}

Rose $^{12)}$ はボールミル中の金属摩耗に関与すると思わ れるすへての因子をとりあげ，次元解析によって無次元 式を導いたが，各無次元項は既存のデータより整理でき るるのは整理し, 結局ボール 1 個当りの摩耗量 $W_{0}$ は次 式で近似されるとしている，

$$
W_{b}=K D_{m}^{2.65}\left(N / N_{c}\right) D_{b}^{2.0} L t
$$

ここで $D_{m}$ はミル径， $L$ はミルの長さ， $t$ は粉碎時間 である。なお $K$ の値はいろいろな人のデータを平均し て, c. g. s. 単位でほほ $1.6 \times 10^{-8}$ とおいて大きい違いは ないとしている。

このような諸因子の影箘については，最近では Plausen"), Bernutat ${ }^{1)}$ らあかなり詳しく娭討を行なってい るが，多くの研究結果および実際の工莱的データを整理 して，一応経験的に諸因子の影覃を図示したるのに Wellinger とUetz の研究があっで7), 被粉碀物の種 類, ボールの材質などの点についてもかなり詳しい。ま たボール材質については，セラミックボールも含めて山 内・西山の詳しい実験 ${ }^{18)}$ がある，

文

1) Bernutat, P. : Zement-Kalk-Gips, 53, 397 400 (1964)

2) Bond, F. C. : Trans. Amer. Inst. min. (metall.) Engrs., 153, 373 (1943)

3) Bond, F. C. : Min. Engg., 10, 592 (1958)

4) Bond, F. C. : C. E. P, 60, 90 93 (1964)

5) DSIR: "Crushing \& Grinding-A Bibliography", HMSO, London, 1958

6) Hukki, R. T. : Trans. Amer. Inst. min. (metall.) Engrs., 190, 642 (1954)

7) 神保元二：邪工学研究会能, 1，32３7 (1964）

\begin{tabular}{|c|c|c|c|}
\hline 物 而 & 比孟 & 仕办指数 $W_{i}$ & 睡耗指数 $A_{2}$ \\
\hline Dolomite & 2.7 & $\cdots$ & 0.0160 \\
\hline Limestone & 2.7 & 11.7 & 0.0320 \\
\hline Cement clinker & 3.2 & 13.5 & 0.0713 \\
\hline Copper ore & 3.0 & 11.7 & 0.1472 \\
\hline Hematite & 4.2 & 8.5 & 0.1647 \\
\hline Magnetite & 3.7 & 13.0 & 0.2217 \\
\hline Granite & 2.7 & 16.6 & 0.3880 \\
\hline Taconite & 3.4 & 16.3 & 0.6237 \\
\hline Alumina & 3.9 & 17.5 & 0.8911 \\
\hline
\end{tabular}

表 2 Bond の摩耗指 数4)

また振動ボールミル中での金属察耗については， Ro$\mathrm{se}^{13)}$, Rose・神(保 ${ }^{14)}$ の研究があって，やはり無次元式 でまとめられている。

\section{5. ホホールの形状变化}

ボールが摩耗していくとき必ずしる均一な摩耗が進行 せず，一般に球形のものが多面体状になっていくことが 多いといわれるが，このような点についての研究はあま り見当らない。山内・西山息は各種材料のボールとシ ルペブについて形状变化をみており,鈴木 ${ }^{16)}$ はシルベブ では径と長さの減少速度がそれぞれ異なることを見出し ている。

\section{6. 糜耗性の試殹法}

Bond は Allis-Chalmers Research Laboratory $の$ 試験法（1956）を紹介している゙か，この上らな試みが 比較的少ないたけに注目すべきのといえよう。その方 法はドラム中に試料粉体を入れ，その中で規格を定めた 試験棒をまわし, 試験棒金属の摩耗量（減量）をるって 摩耗指数（Abrasion Index, $A_{i}$ ）とするすのである。 この摩耗指数の值を数例について上げると表 2 のよ5で あるそしてこの $A_{1}$ の値からミル中の金属摩耗量 ( $1 \mathrm{~b} /$ $\mathrm{kWh}$ ）を求める経験式を各種のミルについて求めてい るが，いかにもBond らしく豊富なデータに襄つけされ た整理として有用であろう。

\section{献}

8）三茂雄：化学工场，8，No.3 p.17 (1964)

9) Paulsen, H. : Zement-Kalk-Gips, 53, 392 396 (1964)

10) Prentice, T. K. : Trans. Amer. Inst. min. (metall.) Engrs, 169, 147 54 (1946)

11) Rasumow, K. A. : in "Feinmahlen der Erze" VEB-Verlag Technik, Berlin (1954), Übersetzung aus dem Russischen.

12) Rose, H. E., R. M. E. Sullivan: A Treatise on the Internal Mechanics of Ball, Tube and Rod Mills, Constable, London, 1958

13) Rose, H. E., R. M. E. Sullivan: Vibration Mills and 
Vibration Milling, Constable, London (1961)

14) Rose, H. E., G. Jimbo: Trans. Instn Chem. Engrs., 41, $147 \sim 158$ (1963)

15) Storek, F., J. Vrsek \& J. Likes : Reports of the Czechoslovak Metallurgical Research (in Czech), 3, 89 92(1959)
16）领木末男：七メント技術大会，1964 年（private communication)

17) Wellinger, K., H. Uetz: Zement-Kalk-Gips, 54, 52 63 (1965)

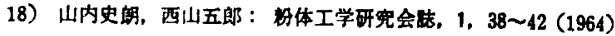

$\mathrm{XIX}-\mathrm{II} \cdot 3 \cdot(4)$ 自 生 粉 砕*

井上外志雄**

\section{1. 概说}

自生粉砕（autogenous grinding）とはボールあるい はロッドのようないわゆる粉砕媒体 (grinding media) を使わず，被粉碎物相互間の力学的作用のみによって 行なら粉碀法である。この技術は現在までのところ，主 として釷莱における比校的大規模な粉碎工程に用いられ ており、すぐれた自生粉砕ミルの開発と相まって, 経済 的に妙味のある方法として最近とくに脚光を浴びるよ5 になった。自生粉碎においては本来，原料をそのまま回 転ミルにフィードして一段で取終希望産物粒度（たとえ ばー74 $\mu$ ）にまで粉砝することが可能である。この場 合，原料中の粗粒部分は粉砕媒体の代りの役を果たすの で，原料はある程度粗粒の（少なくとも50 $\mathrm{mm}$ 以上)粒 子を含んでいることが必要である。ミルの權造および操 举条件の設定に当っては，これらを原料の粒度棈成およ び被粉碎特性に適合させるためにボールミル，口ッドミ

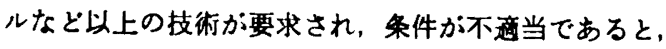
たとえば中間粒度の粒子がミル内に苦積されて粉碀機能 を損ならというよらな問题を生ずる。そこでこのような 問㞘に対する解決策として，取近では原料をあらかじめ

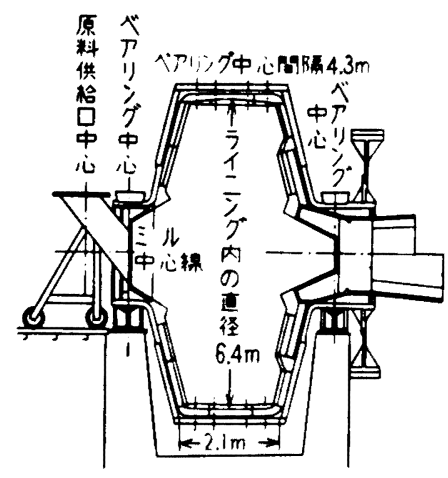

国 1 カスケード・エ

- 昭和 40 年6月11日 受理

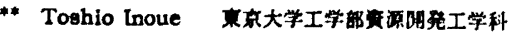

フルイ分けて配合フィードしたり，補助的粉砕媒体とし て若干のボールを装入するなどの方法がとられ，またミ ルの回枟速度をたとえばワードレオナード駆動方式によ り任意に調節するようなことも行なわれている。

自生粉砕の技術には大きく見て二つの流れがある。す なわち，第1は格子排出型（grate discharge type）ボ 一ルミルによるいわゆるべブルミルより発展したもので あり，第 2 は自生粉碀のためにとくに設計された粉砕機 によるすのである。このよ5な自生粉砕機としては古く はハドセルミルがあったが，最近これに代って後述のカ スケードミルとエロフォールミルが出現し，世界的普及 を見るに至っている。カスケードミルとェロフォールミ ルについては今泉らが紹介している2(1。

\section{2. 自生粉杂技術における樶近の進步}

\section{$2 \cdot 1$ ペフルミル方式の自生粉矺}

ペブルミルはボールやロッドの代わりに玉石(ペブル) を粉砕媒体として用いるミルであるが，ベブルを被粉研 原料塊自体に圈きかえることによって，これを自生粉挽 に利用することができる。ベブルまたは原料塊（たとえ ば塊鉣石）は鉄材の粉破媒体と比较して比重が小さいの で，粉确奻果をあげるために，とくに考虑を払5必要が ある。そこで，この種の自生粉砕ミルの操莱において は, 主としてリフターの使用, ミル回転速度の增大およ び格子排出機構による低ハハプレペル方式の採用によっ て,この問題に対処している。またミルの直径すある程 度大きい方が有利である（たとえば $3.6 \mathrm{~m}, 5.7 \mathrm{~m}$ )。鉄

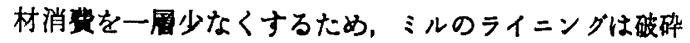
原料の充填居またはゴムによってなされる場合がある。

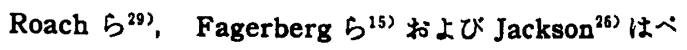
ブルミル方式による自生粉碀の実際，とくに原料粒度の 調整，粉碎回路方式の決定，他粉碎方式との比較などに 闺して興味ある資料を提供している。 